\title{
Pengaruh Gaya Kepemimpinan, Budaya Organisasi aan Pelatihan terhadap Kinerja Karyawan di Rumah Sakit Pondok Indah
}

\author{
Oleh : Enny Khotimah \\ Mahasiswa Program Doktor Ekonomi Uiversitas Borobudur Jakarta \\ Email : ennykesehatan17@gmail.com
}

\begin{abstract}
This study examines the effect of leadership style, organizational culture and training on employee performance at Pondok Indah Hospital. The study was conducted at Pondok Indah Hospital in South Jakarta.

The population of this research is in the Division of Hospitality Employee Services Department and Laboratory at Pondok Indah Hospital. The study population numbered is 140 people. While the study sample as many as 104 people. This study uses Proportional random sampling method and data used in this study is primary data in the form of a questionnaire. The test results showed that the Leadership Style, Organizational Culture and Training is a variable determinant of employee performance.

Partially Leadership Style does not affect the performance of employees, organizational culture does not affect the performance of employee, training a strong influence on employee performance.

Leadership style, organizational culture and training together have a significant impact on the performance of employees in the hospitality division and Laboratory Services Department at Pondok Indah Hospital.
\end{abstract}

Keywords : leadership styles, organizational culture, training, performance 


\section{PENDAHULUAN}

Industri rumah sakit di Indonesia beberapa tahun belakangan ini telah mengalami perkembangan yang cukup berarti, khususnya pada peningkatan jumlah RS swasta. Hal ini tentu membuat persaingan antar Rumah sakit semakin meningkat. Oleh karena itu setiap Rumah Sakit perlu memperbaiki kualitasnya untuk dapat bersaing dengan kompetitor. Era Globalisasi dunia usaha ditandai dengan terbukanya persaingan yang hebat di segala bidang, termasuk pada jasa pelayanan kesehatan (Rumah Sakit). Organisasi menghargai tantangan untuk mampu meningkatkan kualitas SDM agar memiliki keahlian khusus sehingga mampu bersaing dengan dunia usaha. Agar perusahaan tetap esksis maka harus berani menghadapi tantangan dan implikasinya, yaitu menghadapi perubahan dan memenangkan pesaingan. Sumber Daya Manusia yang dimiliki perusahaan seperti modal, metode dan mesin tidak bisa memberikan hasil yang optimum apabila tidak didukung oleh SDM yang mempuyai kinerja yang Optimum. Douglas (2000) menjelaskan bahwa perusahaan membutuhkan karyawan yang mempunyai kinerja (job performance) yang tinggi.

Organisasi Rumah Sakit mempunyai sejumlah sifat-sifat yang tidak dimiliki oleh organisasi lain pada umumnya yaitu sebagian besar SDM nya adalah tenaga profesional, beban kerja tidak bisa diatur, jumlah dan sifat pekerjaanya sangat beragam dan output yang tidak bisa distandarisasi. Pelayanan Rumah sakit sifatnya individualistik. Setiap pasien harus dipandang sebagi individu yang utuh, aspek fisik, aspek mental, aspek sosio kultural, dan aspek spiritual harus mendapat perhatian penuh. Pelayanan tidak bisa diberikan secara hitungan, pengendalian mutu pelayanan kesehatan sangat diperlukan.

Rumah Sakit merupakan organisasi pelayanan jasa yang mempunyai kespesifikan dalam hal SDM (Suber Daya Manusia). Rumah Sakit dikatakan sebagai organisasi yang padat modal, padat sumber daya manusia, padat ilmu pengetahuan, padat tehnologi, serta padat regulasi,. Padat modal karena rumah sakit memerlukan investasi yang tinggi untuk memenuhi persyaratan yang ada. Padat sumber daya manusia karena di dalam rumah sakit pasti terdapat berbagi profesi dan jumlah karyawan yang banyak. Padat tehnologi dan ilmu pengetahuan karena di dalam rumah sakit terdapat peralatan-peralatan canggih dan mahal serta kebutuhan berbagai disiplin ilmu yang berkembang dengan cepat. Padat regulasi karena banyak regulasi/peraturan yang mengikat berkenaan dengan syarat-syarat pelaksana pelayanan di Rumah Sakit.

Akreditasi Rumah Sakit adalah pengakuan resmi dari pemerintah kepada rumah sakit yang telah memenuhi standar pelayanan kesehatan dan merupakan hasil dari evaluasi formal dalam rangka peningkatan mutu, melalui akreditasi akan didapatkan pula gambaran tentang baik tidaknya kinerja personil rumah sakit dalam melaksanakan tugasnya. Akreditasi akan memberikan jaminan kepada pelanggan dan masyarakat bahwa pelayanan yang diberikan rumah sakit diselnggarakan dengan baik dan sesuai standar (Departemen Kesehatan RI, 2000).

Proses Akreditasi sendiri melibatkan seluruh tenaga atau Sumber Daya Manusia (SDM) di Rumah Sakit mulai dari tenaga medis dan penunjang medis, tenaga keperawatan, farmasi, tenaga manajemen rumah sakit, dan tenaga non kesehatan. Untuk meningkatkan mutu pelayanan Rumah Sakit, diperlukan kinerja karyawan yang baik. Kinerja karyawan dalam menjalankan peran dan fungsinya tidak terlepas dari faktor kepemimpinan, budaya organisasi dan pelatihan. Kepemimpinan merupakan faktor kunci didalam suatu organisasi atau perusahaan, faktor kepemimpinanlah yang akan memberikan warna dan membawa suatu organisasi atau perusahaan mencapai visi melalui misi-misinya. penelitian menunjukan kinerja tenaga kesehatan 
misalnya perawat di Rumah Sakit, berhubungan secara bermakna dengan efektifitas kepemimpinan terkait dengan perencanaan, pengarahan, pelatihan yang pernah dilaksanakan, pengamatan dan penilaian yang dilakukan. Dapat diartikan bahwa jika kepemimpinan manajer perawat baik akan berkontribusi terhadap kinerja perawat pelaksana pada akhirnya akan berkontribusi terhadap mutu pelayanan Rumah Sakit.

Di Lingkungan rumah sakit perlu dikembangkan suatu budaya kerja ke arah positif, maksudnya budaya kerja yang mendukung pencapaian visi, misi dan tujuan. Sesuai dengan perkembangan baru dalam paradigma pelayanan, budaya kerja rumah sakit yang positif adalah budaya kerja melayani. Nilai/Budaya Rumah Sakit Pondok Indah adalah Integritas, Kerja sama Tim, Etika, Semangat \& Keteguhan, Inovasi, Pengembangan Individu, Pembelajaran berkesinambungan. Dari budaya perusahaan yang dimiliki RS Pondok Indah dimana salah satunya berorientasi pada kepuasan pelanggan, dapat dipertanyakan apakah penerapan nilai budaya perusahaan ini dapat mempengaruhi kinerja karyawan di Rumah Sakit Pondok Indah.

Dalam organisasi modern, pelatihan menjadi alat yang penting untuk menciptakan kesiapan dan fleksibilitas dalam menghadapi persaingan kedepan. Pengelolaan pengetahuan dapat mempengaruhi kinerja. Sumber daya manusia di RS Pondok Indah yang meliputi aspek-aspek pendidikan, pengalaman dan ketrampilan dituntut untuk tidak hanya sekedar terlatih secara teknis namun juga mampu menganalisis dan memecahkan permasalahan-permasalahan yang terkait dengan pekerjaan, bekerja secara produktif secara team dan mampu dalam berbagai bidang pekerjaan sesuai dengan disiplin ilmu dan profesi.

\section{BAHAN DAN METODE Gaya Kepemimpinan} Menurut Rivai kepemimpinan adalah pola menyeluruh dari tindakan seorang pemimpin, baik yang tampak maupun yang tidak tampak oleh bawahannya. Gaya kepemimpinan menggambarkan kombinasi yang konsisten dari falsafah, ketrampilan, sifat, dan sikap yang mendasari perilaku seseorang. Gaya kepeimpinan menunjukkan secara langsung maupun tidak langsung, tentang keyakinan seorang pemimpin terhadap kemampuan bawahannya. Artinya, gaya kepemimpinan adalah perilaku dan strategi, sebagai hasil kombinasi dari falsafah, keterampilan, sifat, sikap, yang sering diterapkan seorang pemimpin ketika ia mencoba mempengaruhi kinerja bawahannya.

Flippo (2002) berpendapat gaya kepemimpinan dapat dirumuskan sebagai suatu pola perilaku yang dirancang untuk memadukan kepentingan-kepentingan organisasi dan personalia guna mengejar beberapa sasaran. Sedangkan Miftah Thoha (1983) menyatakan gaya kepemimpinan merupakan norma perilaku yang digunakan oleh seseorang pada saat orang tersebut mencoba mempengaruhi perilaku orang lain seperti yang ia lihat, akan menyelaraskan persepsi diantara orang yang akan mempengaruhi perilaku dengan orang yang perilakunya akan dipengaruhi menjadi amat penting kedudukannya.

Menurut Hadari

menjelaskan bahwa unsur-unsur dalam kepemimpinan adalah :

1. Adanya seseorang yang berfungsi memimpin, yang disebut pemimpin (leader).

2. Adanya orang lain yang dipimpin.

3. Adanya kegiatan yang menggerakkan orang lain yang dilakukan dengan mempengaruhi dan pengarahkan perasaan, pikiran, dan tingkah lakunya.

4. Adanya tujuan yang hendak dicapai dan berlangsung dalam suatu proses di dalam organisasi, baik organisasi besar 
maupun kecil.

Faktor-faktor yang mempengaruhi kepemimpinan Davis menyimpulkan ada empat faktor yang mempengaruhi kepemimpinan dalam organisasi, yaitu :

1. Kecerdasan : seorang pemimpin harus mempunyai kecerdasan yang melebihi para anggotanya. Kematangan dan keluasan sosial: seorang pemimpin biasanya memiliki emosi yang stabil, matang, memiliki aktivitas dan pandangan yang cukup matang

2. Motivasi dalam dan dorongan prestasi : dalam diri seorang pemimpin harus mempunyai motivasi dan dorongan untuk mencapai suatu tujuan.

3. Hubungan manusiawi : pemimpin harus bisa mengenali dan menghargai para anggotanya.

Sunita (1997) dalam Mas'ud (2004), mengatakan gaya kepemimpinan terdiri dari empat dimensi gaya kepemimpinan yaitu:

1. Gaya Otoriter, yaitu gaya kepemimpinan yang tidak membutuhkan pokok- pokok pikiran dari bawahan dan mengutamakan kekuasaan serta prestise sehingga seorang pemimpin mempunyai kepercayaan diri yang tinggi dalam pengambilan keputusan.

2. Gaya Pengasuh, yaitu gaya kepemimpinan dimana pemimpin memperhatikan bawahan dalam peningkatan karier, memberikan bimbingan, arahan, bantuan dan bersikap baik serta menghargai bawahan yang bekerja dengan tepat waktu.

3. Gaya Berorientasi pada tugas, yaitu gaya kepemimpinan dimana seorang pemimpin menuntut bawahan untuk disiplin dalam hal pekerjaan atau tugas.

4. Gaya Partisipatif, yaitu gaya kepemimpinan dimana pemimpin mengharapkan saran-saran dan ide-ide dari bawahan, gaya kepemimpinan partisipatif untuk pengambilan keputusan juga dipengaruhi oleh partisipasi bawahan

Dari definisi-definisi gaya kepemimpinan diatas, maka dapat disimpulkan bahwa " Gaya kepemimpinan adalah adalah perilaku dan strategi, sebagai hasil kombinasi dari falsafah, keterampilan, sifat, sikap, yang sering diterapkan seorang pemimpin ketika ia mencoba mempengaruhi kinerja bawahannya.

Dalam setiap organisasi pasti ingin mencapai tujuan yang telah direncanakan dan untuk mencapai tujuan tersebut diperlukan seorang pemimpin yang memiliki kemampuan untuk menggerakkan orang lain untuk mencapai tujuan tertentu. Kemampuan ini dibutuhkan dalam setiap jenjang dalam organisasi atau perusahaan.

Tanpa adanya leadership yang baik, organisasi tidak akan berjalan efektif. Leadership dibutuhkan untuk memotivasi, menginisiasi, mengkoordinasi, dan membangun lingkungan yang sesuai untuk mencapai tujuan tersebut.

\section{Budaya Organisasi}

Budaya organisasional adalah sistem makna, nilai-nilai dan kepercayaan yang dianut bersama dalam suatu organisasi yang menjadi rujukan untuk bertindak dan membedakan organisasi satu dengan organisasi lain (Mas'ud, 2004).

Secara umum budaya organisasi didefinisikan sebagai serangkaian tata nilai, keyakinan, dan polapola perilaku yang membentuk identitas organisasi serta perilaku para anggotanya (Deshpande dan Farley, 1999). Budaya organisasi, berdasarkan definisi tersebut di atas, dapat ditempatkan pada arah nilai (values) maupun norma perilaku (behavioral norms).

Menurut Robbins (2008) budaya 
organisasi adalah sistem nilai bersama dalam suatu organisasi yang menentukan tingkat bagaimana para karyawan melakukan kegiatan untuk mencapai tujuan organisasi. Budaya organisasi juga didefinisikan sebagai suatu nilai-nilai yang mempedomani sumber daya manusia dalam menghadapi permasalahan eksternal dan usaha memahami nilai-nilai yang ada serta mengerti bagaimana mereka harus bertindak dan bertingkah laku. Semua sumber daya manusia harus dapat memahami dengan benar budaya organisasinya, karena pemahaman ini sangat berkaitan dengan setiap langkah ataupun kegiatan yang dilakukan, baik perencanaan yang bersifat strategis dan taktikal maupun kegiatan impleentasi perencanaan, dimana setiap kegiatan tersebut harus berdasar pada budaya organisasi.

Menurut Robbins (2008) ada sepuluh karateristik kunci yang merupakan inti budaya organisasi,yakni:

1. Member identity, yaitu identitas anggota dalam organisasi secara keseluruhan, dibandingkan dengan identitas dalam kelompok kerja atau bidang profesi masingmasing.

2. Group emphasis, yaitu seberapa besar aktivitas kerja bersama lebih ditekankan dari pada kerja individual

3. People focus, yaitu seberapa jauh keputusan manajemen yang di ambil digunakan untuk mempertimbangkan keputusan tersebut bagi anggota organisasi.

4. Unit integration, yaitu seberapa jauh unitunit di dalam organisasi dikondisikan untuk beroperasi secara terkondisi.

5.Control, yaitu banyaknya/jumlah peraturan dan pengawasan langsung digunakan untuk mengawasi dan mengendalikan prilaku karyawan.

6. Risk tolerance, yaitu besarnya dorongan terhadap karyawan untuk menjadilebih agresif, inovatif, dan berani mengambil resiko.

7. Reward criteria, yaitu berapa besar imbalan di alokasikan sesuai dengan kinerja karyawan di bandingkan alokasi berdasarkan senioritas, favoritism, atau factor-faktor non kinerja lainya.

8. Conflict tolerance yaitu besarnya dorongan yang diberikan kepada karyawan untuk bersikap terbuka terhadap konfik dan kritik.

9. Means-endsorientation, yaitu intensitas manajeman dalam menekankan pada penyabab atau hasil, dibandingkan pada teknik dan proses yang di gunakan untuk mengembangkan hasil.

10. Open-system focus, yaitu besarnya pengawasan organisasidan respon yang di berikan untuk mengubah lingkungan eksternal.

Peneliti Kotter dan Heskett (1997) menyimpulkan bahwa (1) Budaya perusahaan mempunyai pengaruh yang sangat dominant terhadap sukses tidaknya perusahaan membangun kinerja karyawan. (2) Budaya organisasi mempunyai dampak positif terhadap kinerja ekonomi perusahaan. (3) Budaya organisasi dapat diciptakan dan dibentuk untuk meningkatkan kinerja organisasi.

Brahmasari dan Suprayetno (2008) mengemukakan bahwa budaya organisasi sebagai suatu konsep dapat menjadi suatu sarana untuk mengukur kesesuaian dari tujuan organisasi, strategi dan organisasi tugas, serta dampak yang dihasilkan. Budaya yang ada pada suatu perusahaan menyebabkan para pekerja memiliki cara pandang yang sama dalam melaksanakan aktivitas pekerjaan. Budaya berhubungan dengan bagaimana perusahaan membangun komitmen mewujudkan visi, memenangkan hati pelanggan, memenangkan persaingan dan membangun kekuatan perusahaan

Dari definisi-definisi Budaya Organisasi diatas, maka dapat disimpulkan bahwa "Budaya organisasi adalah sistem kepercayaan dan sikap bersama yang berkembang dalam suatu organisasi dan membimbing perilaku para anggotanya. Selain itu, budaya organisasi juga dapat didefinisikan sebagai filosofi, ideologi, 
nilai-nilai, asumsi, kepercayaan, harapan, sikap dan norma-norma yang menyatukan suatu organisasi serta disebarluaskan oleh para karyawannya.

budaya organisasi merupakan konsep yang terus berkembang dan harus diperhatikan dalam suatu organisasi untuk berhasil menciptakan budaya yang baik dalam perusahaan.

\section{Pelatihan}

Rivai (2004) menyatakan bahwa, "Pelatihan adalah proses secara sistematis mengubah tingkah laku karyawan untuk mencapai tujuan organisasi. Pelatihan berkaitan dengan keahlian dan kemampuan karyawan untuk melaksanakan pekerjaan saat ini. Pelatihan memiliki orientasi saat ini dan membantu karyawan untuk mencapai keahlian dan kemampuan tertentu agar berhasil dalam melaksanakan pekerjaannya.

Pengertian pelatihan secara sederhana didefinisikan oleh Pramudyo (2007) sebagai Proses pembelajaran yang dirancang untuk mengubah kinerja orang dalam melakukan pekerjaannya Yang dimaksud dalam hal ini adalah adanya empat hal yang harus diperhatikan. Yaitu proses pelatihan, kinerja, peserta pelatihan, dan pekerjaan.

Mangkuprawira (2009) menjelaskan bahwa : "Pelatihan adalah sebuah proses mengajarkan pengetahuan dan keahlian tertentu serta sikap agar karyawan semakin terampil dan mampu melaksanakan tanggung jawab dengan semakin baik, sesuai dengan standar". Proses kegiatan pelatihan sering dilaksanakan oleh suatu perusahaan setelah terjadi penerimaan karyawan sebab latihan hanya diberikan pada karyawan dari perusahaan yang bersangkutan. Latihan adakalanya diberikan setelah karyawan tersebut ditempatkan dan ditugaskan sesuai dengan bidangnya masing-masing. Tujuan pelatihan menurut Mangkunegara (2009) antara lain :

1. Meningkatkan penghayatan jiwa dan ideology

2. Meningkatkan produktivitas kerja
3. Meningkatkan kualitas kerja

4. Meningkatkan perencanaan sumber daya manusia

5. Meningkatkan sikap moral dan semangat kerja

6. Meningkatkan rangsangan agar karyawan berprestasi secara maksimal

7. Meningkatkan kesehatan dan keselamatan.

8. Menghindarkan keseragaman

9. Meningkatkan perkembangan pribadi karyawan.

Umar (2005) mengemukakan bahwa : "Program pelatihan bertujuan untuk memperbaiki penguasaan berbagai keterampilan dan teknik pelaksanaan kerja untuk kebutuhan sekarang". Setiap perusahaan yang menjalankan pelatihan, membutuhkan metode yang tepat agar isi pelatihan tersebut dapat dengan mudah diresap oleh para karyawan yang menjadi peserta pelatihan. Metode tersebut antara lain : Metode Pekerjaan (On The Job Training), Metode Balai (Vestibule), Metode Demonstrasi dan Contoh, Metode Apprenticeship, Metode Simulasi.

Sikula dalam Mangkunegara (2009) mengemukakan bahwa pelatihan (training) adalah suatu proses pendidikan jangka pendek yang mempergunakan prosedur sistematis dan terorganisasi, pegawai non manajerial mempelajari pengetahuan dan keterampilan teknis dalam tujuan yang terbatas. Pengembangan merupakan suatu proses pendidikan jangka panjang yang mempergunakan prosedur sistematis terorganisasi yang pegawai manajerialnya mempelajari pengetahuan konseptual dan teoritis untuk mencapai tujuan yang umum. Ada beberapa alasan mengapa pelatihan harus dilakukan atau menjadi bagian yang sangat penting dari kegiatan manajemen sumber daya manusia. Menurut Mangkunegara (2009) alasan-alasan dilaksanakannya, di antaranya sebagai berikut:

1. Adanya pegawai baru: pegawai-pegawai baru sangat memerlukan pelaihan orientasi. Mereka perlu tujuan, aturan, 
dan pedoman kerja yang ada pada organisasi perusahaan. Di samping itu, mereka perlu memahami kewajiban, hak dan tugasnya sesuai dengan pekerjaannya.

2. Adanya penemuan-penemuan baru: Dengan kemajuan ilmu pengetahuan dan teknologi modern, banyak ditemukan peralatan-peralatan baru yang lebih canggih daripada peralatan kantor yang digunakan sebelumnya. Maka itu para pegawai perlu mendapatkan pelatihan agar dapat menggunakannya dengan sebaikbaiknya.

Dari definisi-definisi Pelatihan diatas, maka dapat disimpulkan bahwa "Pelatihan adalah salah satu aspek penting dalam usaha meningkatkan keunggulan bersaing organisasi perusahaan. Adanya perubahanperubahan lingkungan bisnis, lingkungan kerja, menghendaki perusahaan harus melakukan pelatihan sumber daya manusianya secara proaktif, demi mencapai produktivitas kerja yang lebih baik.

\section{Kinerja Karyawan}

Kinerja (performance)adalah hasil kerja yang dapat dicapai oleh seseorang atau sekelompok orang dalam suatu organisasi, sesuai dengan wewenang dan tanggung jawab masing-masing dalam rangka upaya mencapai tujuan organisasi bersangkutan secara legal tidak melanggar hukum dan sesuai dengan moral ataupun etika. Suyadi (1999) menyatakan kinerja adalah hasil kerja yang dapat dicapai oleh seseorang atau sekelompok orang dalam suatu organisasi sesuai dengan wewenang dan tanggung jawab dalam rangka mencapai tujuan organisasi.

Kinerja seorang karyawan akan baik bila sekelompok karyawan dan atasanya mempunyai kinerja yang baik, maka akan berdampak pada kinerja perusahaan yang baik pula (Mathis dan Jackson, 2001). Kinerja berhubungan dengan hasil kerja yang telah dilaksanakan oleh pengelola organisasi.

Keberhasilan suatu organisasi dipengaruhi oleh kinerja (job performance) karyawan, untuk itu setiap perusahaan akan berusaha untuk meningkatkan kinerja karyawannya dalam mencapai tujuan organisasi yangtelah ditetapkan. Kinerja karyawan mengacu pada prestasi seseorang yang diukur berdasarkan standar dan kriteria yang ditetapkan oleh perusahaan. Pengelolaan untuk mencapai kinerja sumber daya manusia tinggi dimaksudkan guna meningkatkan perusahaan secara keseluruhan (Mas'ud, 2004).

Sinambela mengemukkan bahwa kinerja pegawai didefinisikan sebagai kemampuan pegawai dalam melakukan sesuatu keahlian tertentu. Kinerja pegawai sangatlah perlu sebab dengan kinerja ini akan diketahui seberapa jauh kemampuan pegawai dalam melaksanakan tugas yang dibebankan kepadanya.

Robbin mengemukakan bahwa kinerja diartikan sebagai evaluasi terhadap pekerjaan yang dilakukan individu dibandingkan dengan kriteria yang ditetapkan bersama. (Robbin, 2008).

Kinerja adalah hasil kerja yang dapat dicapai oleh sekelompok orang dalam suatu organisasi sesuai dengan wewenang dan tanggungjawab masingmasing, dalam rangka upaya mencapai tujuan organisasi bersangkutan secara legal tidak melanggar hukumdan sesuai dengan moral dan etika (Prawirosentono:1999).

Menurut Waldman (1994) kinerja merupakan gabungan perilaku dengan prestasi dari apa yang diharapkan dan pilihannya atau bagian syarat-syarat tugas yang ada pada masing-masing individu dalam organisasi.

Menurut Simanjuntak

(2005)

kinerja dipengaruhi oleh:

1. Kualitas dan kemampuan pegawai. Yaitu hal-hal yang berhubungan dengan pendidikan/pelatihan, etos kerja, motivasi kerja, sikap mental dan kondisi fisik pegawai.

2. Sarana pendukung, yaitu hal yang berhubungan dengan lingkungan kerja (keselamatan kerja, kesehatan kerja, 
sarana produksi, teknologi) dan hal -hal yang berhubungan dengan kesejahteraan pegawai (upah/gaji, jaminan sosial, keamanan kerja).

3. Supra sarana, yaitu hal - hal yang berhubungan dengan kebijaksanaan pemerintah dan hubungan industrial manajemen.

Kinerja menurut Mangkunegara (2009) adalah hasil kerja secara kualitas dan kuantitas yang dicapai oleh seorang pegawai dalam melaksanakan tugasnya sesuai dengan tanggungjawab yang diberikan kepadanya. Indikator kinerja menurut Mangkunegara (2009), yaitu : Kualitas, Kuantitas, Kehandalan, Sikap.

Dari definisi-definisi Kinerja karyawan diatas, maka dapat disimpulkan bahwa "Kinerja karyawan adalah kesediaan seseorang atau kelompok orang untuk melakukan sesuatu kegiatan dan menyempurnakannya sesuai dengan tanggugjawabnya dengan hasil yang seperti yang diharapkan.

\section{Kinerja Karyawan}

Kinerja karyawan sangat berpengaruh bagi kesuksesan sebuah perusahaan. Kinerja karyawan yang bagus akan berbanding lurus dengan hasil baik dalam perkembangan bisnis perusahaan. Sebaliknya, kinerja yang buruk akan berdampak buruk pula pada perusahaan. Hasil performa karyawan ini dapat dilihat dari aspek kualitas, kuantitas, waktu kerja, dan kerja sama untuk mencapai tujuan yang sudah ditetapkan oleh perusahaan. Semuanya tergantung pada kuantitas dan waktu yang digunakan karyawan dalam menjalankan tugas.

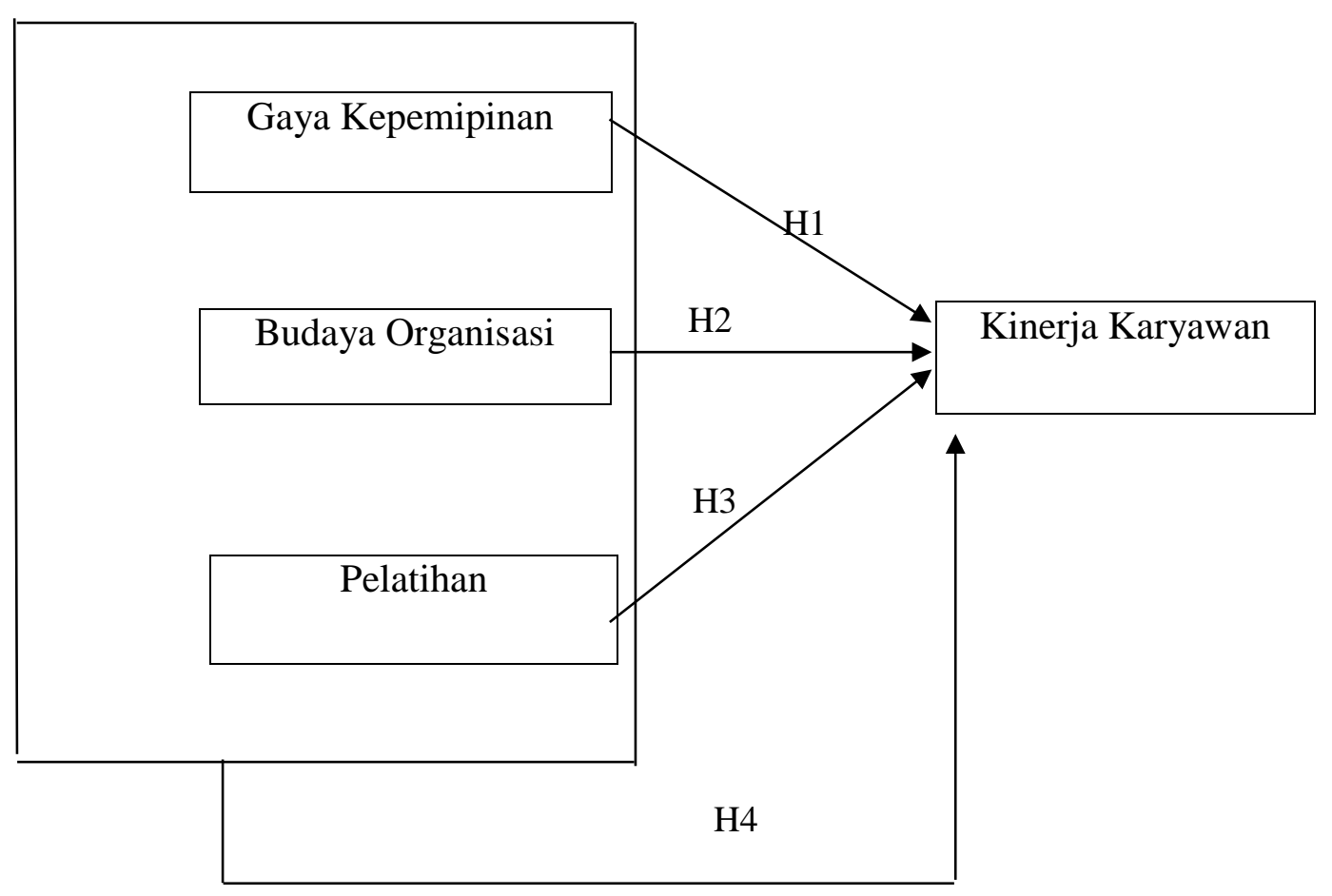

Gambar 1. Kerangka Pemikiran Teoritis 


\subsection{Hipotesis}

Sugiyono (2017:95) berpendapat bahwa hipotesis adalah: "Jawaban sementara terhadap rumusan masalah penelitian, dimana rumusan masalah penelitian telah dinyatakan dalam bentuk kalimat pertanyaan, dikatakan sementara karena jawaban yang diberikan hanya didasarkan pada teori relevan, belum didasarkan pada fakta fakta empiris yang diperoleh melalui pengumpulan data.

Berdasarkan latar belakang masalah dan kerangka pemikiran, maka perumusan hipotesis sebagai berikut :

- H1 : Gaya Kepemimpina pengaruh positif terhadap kinerja karyawan di bagian Laboratorium dan HSD di Rumah Sakit Pondok Indah

- H2 : Budaya Organisasi pengaruh positif terhadap kinerja karyawan di bagian Laboratorium dan HSD di Rumah Sakit Pondok Indah.

- H3 : Pelatihan berpengaruh positif terhadap kinerja karyawan di bagian Laboratorium dan HSD di Rumah Sakit Pondok Indah

- H4 : terdapat pengaruh pada gaya kepemimpinan, budaya organisasi dan pelatihan terhadap kinerja karyawan.

\section{METODE PENELITIAN}

\section{Teknik Analisis Data}

Teknik analisis data yang digunakan dalam penelitian ini adalah analisis regresi linier berganda. Analisis regresi linier berganda digunakan untuk menganalisis pengaruh variabel independen yang terdiri dari: Budaya Organisasi (X1), Kompensasi (X2) ,Kompetensi (X3), Kinerja Karyawan (Y).

Persamaan regresi linier berganda dalam penelitian ini dapat ditulis sebagai berikut :

$$
\begin{aligned}
& \mathrm{Y}=\mathrm{a}+\mathrm{b} 1 \mathrm{X} 1+\mathrm{b} 2 \mathrm{X} 2+\mathrm{b} 3 \mathrm{X} 3+\mathrm{e} \\
& \text { Dimana : } \\
& \mathrm{Y}=\text { Kinerja karyawan } \\
& \mathrm{X} 1 \text { = Budaya organisasi }
\end{aligned}
$$

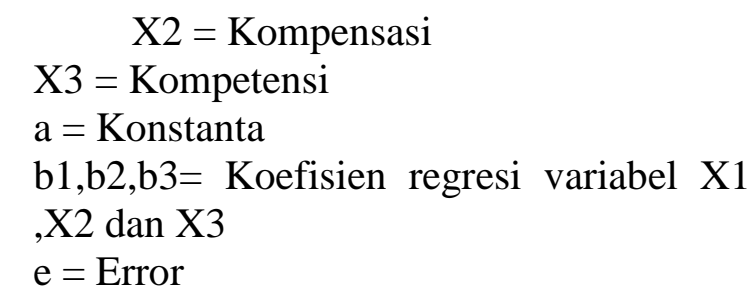

\subsection{Uji Validitas}

Uji validitas digunakan untuk menunjukkan sejauh mana suatu pertanyaan pada suatu angket mampu untuk mengungkapkan sesuatu yang akan diukur oleh angket tersebut. Uji validitas ini memastikan bahwa masing-masing pertanyaan akan terklasifikasikan pada variabel-variabel yang telah ditetapkan (construcvalidity).

Pengujian validitas instrumen dalam penelitian ini dilakukan dengan cara membandingkan nilai Correlated Item Total Correlation pada setiap butir pertanyaan dengan nilai $\mathrm{r}$ tabel. Jika nilai Correlated Item-Total Correlation ( $\mathrm{r}$ hitung ) > nilai $r$ tabel dan nilainya positif, maka butir pertanyaan pada setiap variabel penelitian dinyatakan valid ( Ghozali, 2005)

1. Jika $\mathrm{r}$ hitung $>\mathrm{r}$ tabel dan bernilai positif, maka variabel tersebut valid.

2. Jika $r$ hitung $<\mathrm{r}$ tabel, maka variabel tersebut tidak valid.

\section{Uji Reliabilitas}

Uji reliabilitas digunakan untuk mengukur apakah jawaban seorang responden konsisten atau stabil dari waktu ke waktu. Apabila responden konsisten dalam menjawab pertanyaan dalam angket, maka data tersebut adalah reliabel. Pengujian reliabilitas instrument dalam penelitian ini menggunakan one shot atau pengukuran sekali saja dan untuk pengujian reliabilitasnya digunakan uji statistic Cronbach Alpha. Suatu konstruk atau variabel dikatakan reliabel jika memberikan nilai Cronbach Alpha $>0,60$ ( Ghozali, 2005). 


\subsection{P}

\section{Pengujian Asumsi Klasik}

Sebelum pengujian hipotesis dilakukan uji asumsi klasik untuk memastikan bahwa alat uji statistik linier berganda dapat digunakan atau tidak.Oleh karena itu perlu dilakukan Uji Normalitas, Uji Multikolinieritas dan uji Heteroskedastisitas.

\section{Uji Normalitas}

Uji normalitas bertujuan untuk menguji apakah dalam model regresi, variable pengganggu atau residual memiliki distribusi normal. Dalam uji t dan uji $F$ diasumsikan bahwa nilai residual mengikuti distribusi normal. Ghozali (2005) menyatakan bahwa, ada dua cara untuk mendeteksi apakah residual berdistribusi normal atau tidak yaitu dengan analisis grafik dan uji statistik. Untuk melihat normalitas residual dilakukan dengan melihat normal probability plot yang membandingkan distribusi kumulatif dari distribusi normal. Distribusi normal akan membentuk satu garis lurus diagonal, dan ploting data residual akan dibandingkan dengan garis diagonal. Jika distribusi data residual normal, maka garis yang menggambarkan data sesungguhnya akan mengikuti garis diagonalnya.

\section{Uji Multikolinieritas}

bertujuan untuk menguji apakah model regresi ditemukan adanya korelasi antar variabel bebas (independen). Model regresi yang baik seharusnya tidak terjadi korelasi antar variabel independen. Menurut Ghozali (2005) bahwa ; jika variabel independen saling berkorelasi, maka variabel ini tidak ortogonal. Variabel ortogonal adalah variabel independen yang nilai korelasi antar sesama variabel independen sama dengan nol. Untuk mendeteksi ada tidaknya multikolinieritas di dalam model regresi dapat dilihat dari nilai tolerance dan Variance Inflation Factor (VIF) Variance Inflation Factor (VIF), jika nilai tolerance $\langle 0,10$ atau nilai $\mathrm{VIF}>$ 10 berarti terdapat multikolinieritas.

3.Uji Heteroskedastisitas.

bertujuan menguji apakah dalam model regresi terjadi ketidaksamaan variance dari residual satu pengamatan ke pengamatan yang lain..Heteroskedastisitas pada penelitaian ini dengan melihat grafik plot antara nilai prediksi variabel dependen dengan risidualnya, dengan dasar analisis sebagai berikut Jika ada pola tertentu seperti titik-titik yang ada membentuk pola tertentu yang teratur (bergelombang, melebar, kemudian menyempit), maka mengindikasikan telah terjadi heteroskedastisitas. Jika tidak ada pola yang jelas, serta titiktitik menyebar diatas dan dibawah angka 0 pada sumbu Y, maka tidak terjadi heteroskedastisitas.

\section{Uji Signifikansi}

Hipotesis yang diajukan dalam penelitian ini adalah Gaya Kepemimpinan, Budaya Organisasi dan pelatihan berpengaruh terhadap kinerja karyawan di bagian HSD dan Laboratorium Rumah Sakit Pondok Indah Jakarta. Pengujian hipotesis tersebut dilakukan secara bersama-sama (simultan) dan secara parsial.

Pengaruh variabel independen terhadap variabel dependen diuji dengan tingkat kepercayaan (confidence interval) 95\% atau $\alpha=5 \%$.

1. Uji Signifikan Simultan (Uji F)

Menurut Sanusi (2014:137) uji f digunakan untuk mengetahui apakah variable independent (X) secara bersamasama berpengaruh secara signifikan terhadap variabel dependent (Y) 
pada tingkat kepercayaan $95 \%$ atau $\alpha=$ $5 \%$. Kriteria pengujiannya sebagai berikut:

1. Ho diterima dan Ha ditolak jika Fhitung $\leq$ Ftabel pada $\alpha=5 \%$

2. Ho ditolak dan $\mathrm{Ha}$ diterima jika Fhitung $\geq$ Ftabel pada $\alpha=5 \%$

Rumus yang digunakan untuk menghitung statistik $\mathrm{F}$ ( $\mathrm{F}$ test) adalah sebagai berikut :

$$
\mathrm{F}=\frac{\frac{\mathrm{R}^{2} /\left(\sum \mathrm{Y}^{2}\right)}{\mathrm{k}}}{\frac{\left(1-\mathrm{R}^{2}\right)\left(\sum \mathrm{Y}^{2}\right)}{\mathrm{n}-\mathrm{k}-1}}
$$

\section{Uji Signifikan Parsial ( Uji T)}

Uji Signifikan Parsial (Uji t) Untuk mengetahui apakah koefisien regresi berpangaruh signifikan atau tidak dalam membentuk model regresi, uji t berfungsi untuk menguji apakah koefisien $\beta$ dalam model regresi itu signifikan berpengaruh atau tidak di lakukan uji t. Dengan kriteria pada $\alpha=$ taraf signifikasi dua arah pada derajat 0,05 (Sugiono 2006:281).

Rumus yang digunakan untuk menghitung statistik $\mathrm{t}$ ( $\mathrm{t}$ test) adalah sebagai berikut :

$$
\mathrm{t}=
$$

$$
\mathrm{S}_{\mathrm{bi}}
$$

di mana :

$b_{i}=$ nilai koefisien variabel independen (Xi)

$\mathrm{S}_{\mathrm{bi}}=$ nilai standard error dari variable independen (Xi)

Kriteria pengujian :

- H0 diterima jika $t$ hitung < $\mathrm{t}$ tabel. Hal ini berarti tidak terdapat pengaruh antara $\mathrm{x}$ dengan $\mathrm{y}$. ditolak jika $\mathrm{t}$ hitung $>\mathrm{t}$ tabel. Hal ini berarti terdapat pengaruh yang nyata antara $x$ dengan $y$.

\subsection{Matrik Korelasi}

Matrik Korelasi di bawah ini menggambarkan korelasi antara variabelvariabel manifest. Matrik Korelasi diperlukan untuk mengetahui derajat kedekatan antar variabel. Nilai koefisien korelasi $\mathrm{r}$ berkisar antara -1 sampai +1 . Untuk nilai determinan apabila mendekati nol (0), menunjukan bahwa korelasi antara variabel manifest yang ada cukup tinggi.

\begin{tabular}{|c|c|c|c|c|}
\hline \multirow{2}{*}{\multicolumn{2}{|c|}{ Variabel terikat }} & & & \\
\hline & & $\begin{array}{c}\mathrm{Y}_{1} \\
\text { Kualitas }\end{array}$ & $\begin{array}{c}\mathrm{Y}_{2} \\
\text { Kuantitas }\end{array}$ & $\begin{array}{c}\mathrm{Y}_{3} \\
\text { Kehandalan }\end{array}$ \\
\hline \multirow{4}{*}{$\begin{array}{l}\text { Gaya } \\
\text { kepemimpinan }\end{array}$} & $\mathrm{X}_{1.1}$ & $\mathrm{X}_{1.1 .} \mathrm{Y}_{1}$ & $\mathrm{X}_{1.1 .} \mathrm{Y}_{2}$ & $\mathrm{X}_{1.1 .} \mathrm{Y}_{3}$ \\
\hline & $\mathrm{X}_{1.2}$ & $\mathrm{X}_{1.2 .} \mathrm{Y}_{1}$ & $\mathrm{X}_{1.2 .} \mathrm{Y}_{2}$ & $\mathrm{X}_{1.2 .} \mathrm{Y}_{3}$ \\
\hline & $\mathrm{X}_{1.3}$ & $\mathrm{X}_{1.3 .} \mathrm{Y}_{1}$ & $\mathrm{X}_{1.3 .} \mathrm{Y}_{2}$ & $\mathrm{X}_{1.3 .} . \mathrm{Y}_{3}$ \\
\hline & $\mathrm{X}_{1.4}$ & $\mathrm{X}_{1.4 .} \mathrm{Y}_{1}$ & $\mathrm{X}_{1.4 .} \mathrm{Y}_{2}$ & $\mathrm{X}_{1.4 .} \mathrm{Y}_{3}$ \\
\hline
\end{tabular}

Berikut ini adalah Tabel Matrikorelasi antar dimensi

Tabel 1. Matrik Korelasi antar Dimensi 
Jurnal Ekonomi, Volume 23 Nomor 1, Pebruarí 2021

Copyright@ 2021, oleh Program Pascasarjana, Universitas Borobudur

\begin{tabular}{|l|l|l|l|l|}
\hline \multirow{3}{*}{ Budaya organisasi } & $\mathrm{X}_{2.1}$ & $\mathrm{X}_{2.1 .} \mathrm{Y}_{1}$ & $\mathrm{X}_{2.1 .} \mathrm{Y}_{2}$ & $\mathrm{X}_{2.1} . \mathrm{Y}_{3}$ \\
\cline { 2 - 5 } & $\mathrm{X}_{2.2}$ & $\mathrm{X}_{2.2 .} \mathrm{Y}_{1}$ & $\mathrm{X}_{2.2 .} \mathrm{Y}_{2}$ & $\mathrm{X}_{2.2 .} \mathrm{Y}_{3}$ \\
\cline { 2 - 5 } & $\mathrm{X}_{2.3}$ & $\mathrm{X}_{2.3 .} \mathrm{Y}_{1}$ & $\mathrm{X}_{2.3 .} \mathrm{Y}_{2}$ & $\mathrm{X}_{2.3 .} \mathrm{Y}_{3}$ \\
\hline \multirow{3}{*}{ Pelatihan } & $\mathrm{X}_{3.1}$ & $\mathrm{X}_{3.1 .} \mathrm{Y}_{1}$ & $\mathrm{X}_{3.1 .} \mathrm{Y}_{2}$ & $\mathrm{X}_{3.1 .} \mathrm{Y}_{3}$ \\
\cline { 2 - 5 } & $\mathrm{X}_{3.2}$ & $\mathrm{X}_{3.2 .} \mathrm{Y}_{1}$ & $\mathrm{X}_{3.2 .} \mathrm{Y}_{2}$ & $\mathrm{X}_{3.2 .} \mathrm{Y}_{3}$ \\
\cline { 2 - 5 } & $\mathrm{X}_{3.3}$ & $\mathrm{X}_{3.3 .} \mathrm{Y}_{1}$ & $\mathrm{X}_{3.3 .} \mathrm{Y}_{2}$ & $\mathrm{X}_{3.3 .} \mathrm{Y}_{3}$ \\
\hline
\end{tabular}

\section{HASIL DAN PEMBAHASAN Uji Validitas}

Uji Validitas digunakan untuk mengukur sah atau valid tidaknya suatu kuesioner. Suatu kuesioner dikatakan jika pertanyaan pada kuesioner mampu untuk mengungkapkan sesuatu yang akan diukur oleh kuesiner tersebut (Ghozaeli. 2011:52). Teknik yang digunakan untuk uji validitas ini adalah "korelasi product moment" dari Pearson dengan tingkat kepercayaan $95 \% \quad(\alpha=0,05)$ dilakukan dengan cara mengkorelasikan skor masing-masing item dengan skor totalnya. Adapun hasil uji validitas terhadap variabel sistem Gaya Kepemimpinan, variabel Budaya Organisasi dan variabel Pelatihan dengan menggunakan bantuan aplikasi program SPSS 21. Uji validitas dilakukan dengan menghitung nilai korelasi antar skor masing-masing pernyataan dengan skor total, memakai rumus teknik korelasi Product Moment Pearson yang diolah dengan software SPSS versi 21.00 for windows. Berdasarkan hasil pengujian validitas untuk masing-masing indikator variabel hasil pernyataan sikap yang dirasakan oleh responden terhadap Gaya
Kepemimpinan, Budaya Organisasi, Pelatihan dan Kinerja Karyawan, semua pernyataan lebih besar dari $r$ tabel pada selang kepercayaan 95 persen yaitu sebesar 0,1622. Hal ini menunjukkan bahwa seluruh pernyataan adalah signifikan dan dapat dinyatakan valid sebagai alat ukur penelitian.

\section{Uji Reliabilitas}

Pengujian reliabilitas instrument dalam penelitian ini menggunakan one shot atau pengukuran sekali saja dan untuk pengujian reliabilitasnya digunakan uji statistic Cronbach Alpha. Suatu konstruk atau variabel dikatakan reliabel jika memberikan nilai Cronbach Alpha $>0,60$ ( Ghozali, 2005). Dalam teknik ini, instrument diuji cobakan pada 104 responden dan hasilnya dicatat. Pengolahan teknik acronbach menggunakan bantuan software SPSS versi 21.00 for windows. Berdasarkan hasil pengolahan terhadap variabel sistem gaya kepemimpinan, variabel budaya organisasi, variabel pelatihan dan variabel kinerja karyawan dihasilkan nilai acronbach yang dapat dilihat tabel berikut ini: 
Tabel 2. Hasil Pengujian Reliabilitas

\begin{tabular}{|l|l|l|l|l|}
\hline No & Butir & Variabel & $\begin{array}{l}\text { Cronbach } \\
\text { Alpha }\end{array}$ & Keterangan \\
\hline 1 & a & Gaya Kepemimpinan & 0,928 & Reliabel \\
\hline 2 & b & Budaya Organisasi & 0,776 & Reliabel \\
\hline 3 & c & Pelatihan & 0,903 & Reliabel \\
\hline 4 & d & Kinerja Karyawan & 0,838 & Reliabel \\
\hline & abcd & $\begin{array}{l}\text { Secara bersama-sama } \\
\text { (All Variabel) }\end{array}$ & 0,906 & Reliabel \\
\hline
\end{tabular}

Sumber: Hasil Penelitian yang di olah.

\section{Uji Normalitas}

Tabel 3. Uji Normalitas

One-Sample Kolmogorov-Smirnov Test

\begin{tabular}{|c|c|c|}
\hline & & $\begin{array}{c}\text { Unstandardized } \\
\text { Residual }\end{array}$ \\
\hline $\mathrm{N}$ & & 104 \\
\hline Normal Parameterca,b & Mean &, 0000000 \\
\hline 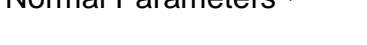 & Std. Deviation & ,35876713 \\
\hline & Absolute &, 087 \\
\hline Most Extreme Differences & Positive & ,059 \\
\hline & Negative &,- 087 \\
\hline Kolmogorov-Smirnov Z & & ,891 \\
\hline Asymp. Sig. (2-tailed) & & ,405 \\
\hline
\end{tabular}

a. Test distribution is Normal.

b. Calculated from data.

Hasil Uji Kolmogorov-Smirnov menunjukatidaknya multikolinearitas diantara variabel bahwa nilai Asymp.Sig pada kolom adalahebas. sebesar di atas 0.405. Nilai lebih besar di atas 0.05 sehingga dapat disimpulkan residual berdistribusi Normal. Dengan demikian dapat disimpulkan bahwa model tidak terkena masalah Normalitas.

\section{Uji Multikolinieritas}

Pada penelitian ini digunakan nilai variance inflantion factorrs (VIF) sebagai indikator ada

Berdasarkan nilai Value Inflation Factor (VIF) yang diperoleh seperti terlihat pada tabel 4.4 sebesar 1.299 , 1.355, dan 1.057. diketahui bahwa tidak ada variabel yang memiliki nilai VIF lebih dari 10, serta nilai tolerance yang kurang dari 0.10 . Dengan demikian asumsi di atas dapat disimpulkan bahwa variabel 
Jurnal Ekonomí, Volume 23 Nomor 1, Pebruarí 2021

Copyright @ 2021, oleh Program Pascasarjana, Universitas Borobudur

independen terbebas dari masalah Multikolinieritas atau asumsi atas mutikoliieritas untuk pengujian regresi ganda telah terpenuhi.

Tabel 4. Hasil Uji Multikolinieritas

\begin{tabular}{|ll|c|c|}
\hline \multirow{2}{*}{ Model } & \multicolumn{2}{|c|}{ Collinearity Statistics } \\
\cline { 3 - 4 } & Tolerance & VIF \\
\hline \multirow{4}{*}{1} & (Constant) & & \\
& Gaya kepemimpinan &, 770 & $\mathbf{1 , 2 9 9}$ \\
& Budaya organisasi &, 738 & $\mathbf{1 , 3 5 5}$ \\
& Pelatihan &, 946 & $\mathbf{1 , 0 5 7}$ \\
\hline
\end{tabular}

\section{Uji Heteroskedastisitas}

Uji heteroskedastisitas digunakan untuk mengetahui ada atau tidaknya penyimpangan asumsi klasik heteroskedastisitas yaitu adanya ketidaksamaan varian dari residual untuk semua pengamatan pada model regresi. Prasyarat yang harus terpenuhi dalam model regresi adalah tidak adanya gejala heteroskedastisitas.

Metode pengujian yang digunakan adalah Melihat pola titik-titik pada scatterplots regresi dengan Melihat pola grafik regresi Metode ini yaitu dengan cara melihat grafik scatterplot antara standardized predicted value (ZPRED) dengan studentized residual (SRESID). Ada tidaknya pola tertentu pada grafik scatterplot antara SRESID dan ZPRED dimana sumbu $\mathrm{Y}$ adalah $\mathrm{Y}$ yang telah diprediksi dan sumbu $\mathrm{X}$ adalah residual (Y prediksi - Y sesungguhnya). Dasar pengambilan keputusan yaitu:

- Jika ada pola tertentu, seperti titik-titik yang ada membentuk suatu pola tertentu yang teratur (bergelombang, melebar kemudian menyempit), maka terjadi heteroskedastisitas.

- Jika tidak ada pola yang jelas, seperti titik-titik menyebar di atas dan di bawah angka 0 pada sumbu $\mathrm{Y}$, maka tidak terjadi heteroskedastisitas.

Dari output dapat diketahui bahwa titik-titik tidak membentuk pola yang jelas, dan titik-titik menyebar di atas dan di bawah angka 0 pada sumbu Y. Jadi dapat disimpulkan bahwa pada model regresi tidak terdapat gejala heteroskedastisitas . 


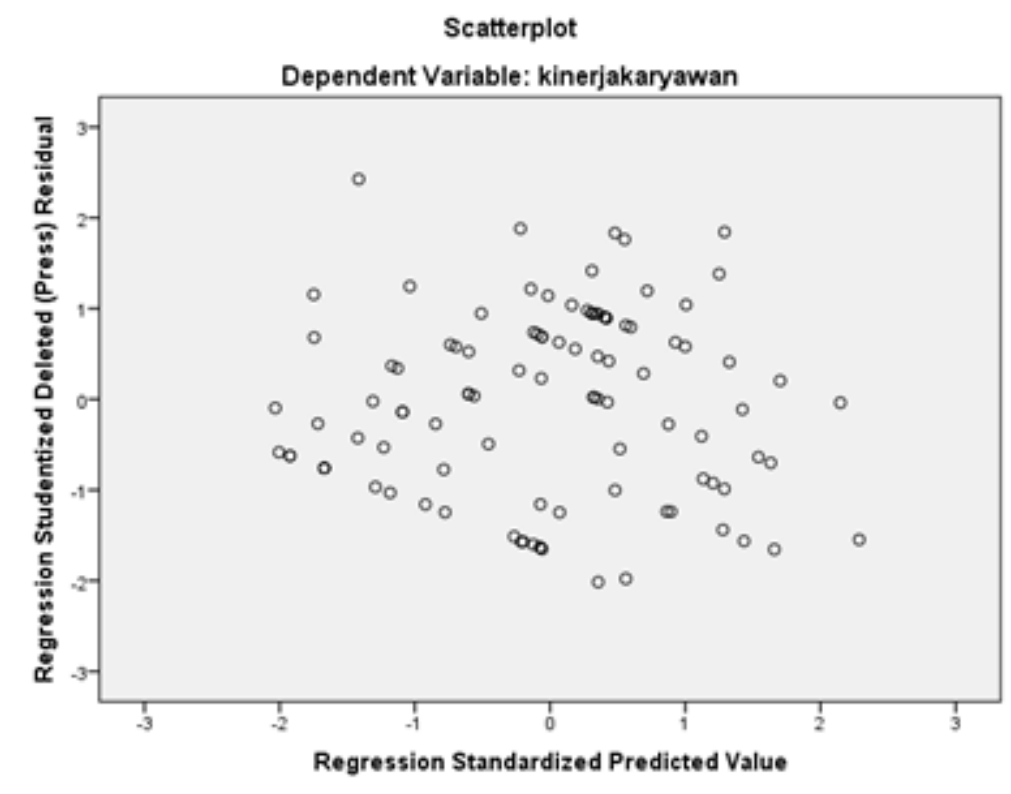

Gambar 2. Hasil Uji Heteroskedastisitas

\section{Analisis Regresi Linier Berganda}

\begin{tabular}{|l|r|r|r|r|r|}
\hline Model & R & R Square & \multicolumn{1}{|c|}{$\begin{array}{c}\text { Adjusted R } \\
\text { Square }\end{array}$} & $\begin{array}{c}\text { Std. Error of } \\
\text { the Estimate }\end{array}$ & $\begin{array}{c}\text { Durbin- } \\
\text { Watson }\end{array}$ \\
\hline 1 &, $\mathbf{4 7 6}^{\mathbf{a}}$ & $\mathbf{, 2 2 7}$ &, 204 &, 364 & 1,531 \\
\hline
\end{tabular}

a. Predictors: (Constant), pelatihan, gaya kepemimpinan, budayaorganisasi

b. Dependent Variable: kinerja karyawan

Nilai koefisien determinasi R2 (R Square) sebesar 0,227 atau $22,7 \%$. Pengaruh gaya kepemimpinan, budaya organisasi dan pelatihan secara bersamasa-sama terhadap kinerja adalah sebesar $22,7 \%$ sedangkan sisanya $77,3 \%$ ditentukan oleh faktor-faktor lainnya. Dengan kata lain bahwa perubahan kinerja karyawan mampu dijelaskan oleh variabel gaya kepemimpinan, budaya organisasi dan pelatihan sebesar $22.7 \%$. Pengaruh lainnya sebesar $77.3 \%$ dijelaskan oleh faktor-faktor lain yang tidak digunakan dalam penelitian ini.

\section{Uji Simultan (Uji F)}


Tabel 7. Hasil Uji Anova/Uji F

ANOVA $^{\text {a }}$

\begin{tabular}{|l|r|r|r|r|l|}
\hline \multicolumn{1}{|l|}{ Model } & \multicolumn{1}{|c|}{$\begin{array}{c}\text { Sum of } \\
\text { Squares }\end{array}$} & \multicolumn{1}{c|}{ Df } & \multicolumn{1}{c|}{$\begin{array}{c}\text { Mean } \\
\text { Square }\end{array}$} & F & Sig. \\
\hline Regression & 3,892 & 3 & 1,297 & $\mathbf{9 , 7 8 6}$ & $\mathbf{, 0 0 0}^{\mathbf{b}}$ \\
Residual & 13,258 & 100 &, 133 & & \\
Total & 17,150 & 103 & & & \\
\hline
\end{tabular}

a. Dependent Variable: kinerjakaryawan

b. Predictors: (Constant), pelatihan, gayakepemimpinan, budayaorganisasi

Uji ini digunakan untuk mengetahui apakah variabel independen (X1,X2....Xn) secara bersama-sama berpengaruh secara signifikan terhadap variabel dependen(Y).

Berdasarkan tabel di atas terlihat nilai $\mathrm{F}$ adalah sebesar 9.786 dengan nilai sig sebesar 0.001. nilai sig sebesai 0.001 bila dibandingkan dengan nilai alpha sebesar $0.005(5 \%)$ adalah lebih kecil. Sehigga dapat disimpulkan bahwa variabel bebas gaya kepemimpinan, budaya organisasi dan pelatihan secara bersama-sama memiliki pengaruh yang signifikan terhadap variabel dependen kinerja karyawan HSD dan Lab di Rumah Sakit Pondok Indah.

Berdasarkan hasil perhitungan analisis regresi linier berganda dengan menggunakan SPSS 21 diperoleh koefisien regresi yang terdapat di tabel di bawah ini. Hasil Pengujian serempak Regresi Variabel Gaya Kepemimpinan, Budaya Organisasi, Pelatihan dan Kinerja karyawan.

\section{Tabel 8. Kofisien Regresi Secara Berganda \\ Coefficients $^{\mathbf{a}}$}

\begin{tabular}{|c|c|c|c|c|c|}
\hline \multirow[t]{2}{*}{ Model } & \multicolumn{2}{|c|}{ Unstandardized Coefficients } & \multirow{2}{*}{$\begin{array}{c}\text { Standardized } \\
\text { Coefficients } \\
\text { Beta } \\
\end{array}$} & \multirow[t]{2}{*}{$\mathrm{t}$} & \multirow[t]{2}{*}{ Sig. } \\
\hline & $\mathrm{B}$ & Std. Error & & & \\
\hline \multirow{4}{*}{$\begin{array}{l}\text { (Constant) } \\
\text { Gaya kepemim } \\
\text { Budaya organ } \\
\text { Pelatihan }\end{array}$} & ,699 &, 177 & & 3,943 & ,000 \\
\hline &,- 001 &, 005 &,- 013 &,- 125 & ,901 \\
\hline & ,148 &, 078 & ,194 & 1,900 & ,060 \\
\hline & ,335 &, 076 & ,400 & 4,421 &, 000 \\
\hline
\end{tabular}

Dependent Variable: kinerja karyawan

diperoleh dari hasil analisis yaitu $\mathrm{Y}$ $=0.699-0,001 \mathrm{X} 1+0,148 \mathrm{X} 2+0,335$ $\mathrm{X} 3$ persamaan regresi tersebut bahwa harga $\alpha 1=-0,001$ bertanda negatif, $\alpha 2=$ 0,148 bertanda positif dan $\alpha 3=0,335$ bertanda positif.

Untuk mengetahui rumus persamaan regresinya dengan $\mathrm{Y}$ adalah variabel dependent kinerja karyawan dan $\mathrm{X}$ adalah variabel independent Gaya Kepemimpinan(X1), Organisasi(X2), dan Pelatihan(X3) dengan melihat hasil tabel 4.8 diketahui nilai constant-nya adalah 0,699 , Gaya Kepemimpinan adalah -0,001, Budaya Organisasi adalah 0.148 , dan Pelatihan 
adalah 0.335 dengan keterangan tersebut dapat diperoleh persamaan regresi :

$$
\text { Ykin }=0,699-0,001 \mathrm{gp} \quad+0,148 \mathrm{bo} \quad 0,335 \mathrm{plt}
$$

independe

n Gaya Kepemimpinan memiliki nilai koefisien regresi sebesar -0.001 dan nilai

dari persamaan di atas dapat diartikan sebagai berikut:

1. Konstanta sebesar 0,699 bermakna jika skor

Gaya Kepemimpinan (X1), Budaya Organisasi (X2) dan Pelatihan (X3) sama dengan nol, maka skor kinerja karyawan tetap sebesar 0,699 dengan nilai signifikansi ,000 yang artinya tanpa pengaruh Gaya Kepemimpinan, Budaya Organisasi, dan Pelatihan maka Kinerja belum memcapai STP atau masih sangat rendah bila di gabung dengan variabel lain baru akan ada pengaruh terhadap Kinerja.

2. Koefisien regresi Xgp sebesar -0,001 menyatakan bahwa setiap penambahan 1 (satu) nilai Xgp akan mengalami penurunan Kinerja sebesar 0,001.

3. Koefisien regresi Xbo sebesar 0,148 menyatakan bahwa setiap penambahan 1 (satu) nilai Xbo akan meningkatkan Kinerja yaitu sebesar 0,148

4. Koefisien regresiXplt sebesar 0,335 menyatakan bahwa setiap penambahan 1 (satu) nilai Xplt akan meningkatkan Kinerja sebesar 0,335.

\section{Pengujian Hipotesis}

\section{Uji Variabel $X_{1}$ (Gaya Kepemimpinan)}

Terlihat pada hasil Uji Parsial tabel diatas diperoleh $t_{\text {hitung }}$ untuk variable $X_{1}$ sebesar 0.125 . Dengan derajat kebebasan $(\mathrm{df})=\mathrm{n}-$ $2=104-2=102$, dengan demikian kriteria pengambilan keputusannya adalah : karena besarnya $t_{\text {hitung }} \mathbf{- 0 . 1 2 5}<\mathrm{t}_{\text {tabel }}$ 1,983, sehingga $\mathrm{H}_{0}$ diterima dan $\mathrm{H}_{1}$ ditolak yang berarti secara parsial (sendiri-sendiri) $\mathrm{X}_{1}$ tidak mempengaruhi Y.

Pada pengujian hipotesis pertama variabel signifikan sebesar 0.901. Nilai Sig tersebut lebih besar dari 0.05 maka hipotesis yang diterima pada pengujian pertama adalah hipotesis $\mathrm{H} 0$ yaitu variabel gaya kepemimpinan tidak berpengaruh positif. terhadap kinerja

\section{Uji Variabel X2 ( Budaya Organisasi)}

Terlihat pada hasil Uji Parsial tabel diatas diperoleh thitung untuk variable X2 sebesar 1.900. Dengan derajat kebebasan $(\mathrm{df})=\mathrm{n}-2=104-2=102$, dengan demikian kriteria pengambilan keputusannya adalah : karena thitung $1.900<$ ttabel1,983 sehingga H0 ditolak dan $\mathrm{H} 1$ yang diterima yang berarti secara parsial (sendiri-sendiri) X2 tidak mempengaruhi Y. Hal ini berarti Budaya Organisasi tidak berpengaruh positif terhadap Kinerja Karyawan.

Pada pengujian hipotesis kedua variabel budaya organisasi memiliki nilai koefisien regresi sebesar 0.148 dan nilai signifikan sebesar 0.060. Nilai Sig tersebut lebih besar dari 0.05 maka hipotesis yang diterima pada pengujian kedua adalah hipotesis H0 yaitu variabel budaya organisasi tidak berpengaruh positif terhadap kinerja.

\section{Uji Variabel X3 (pelatihan)}

Terlihat pada hasil uji parsial tabel di atas diperoleh thitung untuk variabel X3 sebesar 4.421. Dengan derajat kebebasan (df) $=n-2=104-2=102$, dengan demikian kriteria pengambilan keputusannya adalah : karena thitung $4.421>$ ttabel 1,983, sehingga H0 ditolak dan $\mathrm{H} 1$ diterima yang berarti secara parsial (sendiri-sendiri) X3 mempengaruhi Y. 
Pada pengujian hipotesis ketiga variabel pelatihan memiliki nilai koefisien regresi sebesar 0.335 dan nilai signifikan sebesar 0.01. maka hipotesis yang diterima pada pengujian ketiga adalah hipotesis $\mathrm{Ha}$ yaitu variabel pelatihan berpengaruh positif terhadap kinerja.

\section{KESIMPULAN}

Hasil pengujian hipotesis telah membuktikan bahwa gaya kepemimpinan tidak berpengaruh positif terhadap Kinerja karyawan di bagian Hospitality Service Departement dan Laboratorium di Rumah Sakit Pondok Indah. Tetapi pengaruh yang ditimbulkan oleh gaya kepemimpinana adalah pengaruh yang negatif karena nilai koefisien yang dimilikinya bernilai negatif.

Hasil pengujian hipotesis telah membuktikan bahwa budaya organisasi tidak berpengaruh positif terhadap kinerja karyawan di bagian Hospitality Service Departement dan Laboratorium di Rumah Sakit Pondok Indah.

Pelatihan mempengaruhi kinerja karyawan di bagian Hospitality Service Departement dan Laboratorium di Rumah Sakit Pondok Indah.

Dalam hasil penelitian menunjukan gaya kepemimpinan dan budaya organisasi tidak menunjukan pengaruh terhadap kinerja karyawan, tetapi pelatihan mempunyai pengaruh terhadap kinerja karyawan hal ini mengandung arti bahwa Karyawan di bagian Hospitality Service Departement dan Laboratorium di Rumah Sakit Pondok Indah tetap konsisten dengan tugas-tugasnya, mereka melaksanakan tugas sesuai dengan prosedur yang ditetapkan dan memiliki sikap tanggungjawab yang tinggi sehingga mampu mencapai prestasi kerja yang tinggi walaupun pemimpin tidak memberikan kesan yang positif dalam pelaksanaan tugasnya.

Selain itu budaya organisasi yang terbentuk di Rumah Sakit Pondok Indah tidak mempengaruhi kinerja hal ini karena karyawan telah terbiasa dengan budaya melayani kepada pelanggan dengan baik, kerjasama dengan tim yang baik dan memiliki rasa empati serta integritas yang tinggi yang di tanamkan oleh Rumah Sakit Pondok Indah.

Hasil penelitian ini bertolak belakang dengan hasil penelitian terdahulu yang dilakukan Maryam(2009), Thoyib, Setiawan, Salim(2008), Porwani (2009), Brahmasari dan Suprayetno(2008) dimana Gaya Kepemimpinan dan Budaya Organisasi berpengaruh Positif Signifikan terhadap kinerja karyawan.

\section{DAFTAR PUSTAKA}

Armani Thoyib, Margono Setiawan, Ubud Salim. 2008 : "Pengaruh Budaya Organisasi dan Gaya Kepemimpinan serta Pengembangan Karyawan terhadap Kepuasan dan Kinerja Karyawan pada Perusahaan Retail di Sulawesi Selatan:. Tesis. Universitas Hassanudin Makasar.

Avolio BJ, Zhu W, Koh W, Bhatia P. $2004 . \quad$ "Transformational Leadership and Organizationa Commitment: Mediating Role of Psychological Empowerment and Moderating Role of Structural Distance". Journal Organization Behavior. 25(8) :951-68.

Baron, Angela dan Armstrong M. 2013. Human Capital Management. alih bahasa: Lilian Juwono. Penerbit PPM. Jakarta

Bolden, Wilkey, et. al. 2003. Encyclopedy Of Educational Research. Fifth Edition. Ann Lamiel Lady. Pennsylvania

Brahmasari dan Agus Suprayetno. 2008. "Pengaruh Motivasi Kerja, Kepemimpinan dan Budaya Organisasi terhadap Kepuasan Kerja Karyawan serta Dampaknya pada Kinerja Perusahaan (Studi kasus pada 
PT. Pei Hai International Wiratama Indonesia)"

Bass, Bernard $\mathrm{M}$ and Avolio, Bruce J. 1993. "Tansformational Leadership And Organizational Culture". Public Administration Quarterly, 17:1. 112121. Yogyakarta.

Covey, S R, 1992. "Principle Contered Leadership". Free Press ; $1^{\text {st }}$ Edition.

Dasar-dasar

Kepemimpinan

http://leadhership.blogspot.com

diakses tgl 20 Des 2013 pukul 19.00 bbwi

Day Miyamoto dan Junpe Higuchi. 2007. "Paying for Success: Performance Related Pay Systems and its Effects on Firm Performance in Japan" Asian Business \& Management, 2007, 6, (S9-S31).

Deni Primajaya.2010. "Pengaruh Motivasi Kerja dan Pelatihan Kerja terhadap Kinerja Karyawan PT PERTAMINA (Persero)UPS IV Semarang".

Deshpande, R and Farley, J. 1999. "Executive Insight: Corporate Culture and Market Orientation: comparing Indian and Japanese firms", Journal of International Marketing, Vol. 7 No. 4, pp. 111-27

Diane M Gayeksi, Thomas P.Golden, Stephen Andrade, Hilary Mason. 2007. Bringing Competency Analysis Into The 21st Century. Diklat terhadap Kinerja, dan Kepuasan Kerja Karyawan".

Djatmiko Noviantoro. 2009. Analisa Pengaruh Pelatihan dan Pengembangan, serta Kompensasi tehadap Kinerja Pegawai pada PT Perusahaan Perkebunan London Sumatra Ind. Tbk Medan

Edwin B . Flippo. 2002. Personel Management (Manajemen Personalia), Edisi VII Jilid II, Terjemahan Alponso S, Erlangga, Jakarta.

Friday Glorianto. 2005. "Analisa Pengaruh Motivasi Mengikuti Pelatihan dan
Peran Kepemimpinan terhadap Kinerja Karyawan melalui Orientasi Pembelajaran. Studi Kasus pada Kantor Pelayanan Pajak Pekalongan. Diklat Terhadap Kinerja, dan Kepuasan Kerja". Tesis

Handoko T. Hani, 2000, Manajemen Personalia dan Sumberdaya Manusia, Edisi II, Cetakan Keempat Belas, Penerbit BPFE, Yogyakarta.

Husein Umar. 2004. Metode Penelitian untuk Skripsi dan Tesis Bisnis.

Cetakan ke-6. PT Raja Grafindo Persada. Jakarta.

http//wikipedia_indonesia.com diakses tanggal 20 Januari 2013 pukul 20.00 bbwi.

http://www.psychologymania.com/20 12/09/teori-budaya-organisasi.html

diakses tanggal 20 Desember 2013 pukul $20.00 \mathrm{bbwi}$

Jennifer. 1997. "Third wave feminisms." Feminist Studies. College

Park: Spring 1997.Vol. 23, Iss. 1; pg. 97, 12 pgs. Diakses pada 20 Desember 2013 dari http: //proquest.umi.com/pqdweb?did $=11449442 \&$ sid $=1 \&$ Fmt $=3$ \&clie $\mathrm{ntId}=45625 \& \mathrm{RQT}=309 \& \mathrm{VName}=\mathrm{PQ}$ D.

Kotter, JP dan J.L. Heskett. 1997. Corporate Culture and Performance, PT. Prenhallindo. Jakarta.

Kreitner dan Kinicki. 2005. Perilaku Organisasi. Salemba empat. Jakarta.

Luthans, F., 1998. Organizational Behavior, Seventh Edition, International Edition, New York: McGrawHill Companies, Inc.

Mac Gregor, J.G. 1997. Reinforced Concrete : Mechanics and Design. 3rd Ed. Prentice-Hall International, Inc.

Marthis, Robert L. dan Jackson, John H. 2001. Manajemen Sumber Daya Manusia. Salemba Empat. Jakarta. 
Malayu Hasibuan. 2005. Manajemen Sumberdaya Manusia. Bumi Aksara. Jakarta

Mangkunegara, Anwar Prabu. 2009. Manajemen Sumber Daya Manusia Perusahaan. PT. Remaja Rosdakarya. Bandung.

Mariam, Rani, 2009. "Pengaruh Gaya Kepemimpinan dan Budaya Organisasi Terhadap Kinerja Karyawan Melalui Kepuasan Kerja Karyawan Melalui Kepuasan Kerja Karyawan Sebagai Variabel Intervening"Tesis . Semarang: Universitas Diponegoro.

Mujanah, Siti, 2009.'Pengaruh Pelatihan, Kompetensi, dan Kompensasi Terhadap Motivasi Kerja dan Dampaknya Terhadap Kinerja Karyawan di PT Merpati Surabaya". Ekonomi dan bisnis vol 13.No.2.Juni 2009,2 ,hal55-62.

Miftah Thoha, 1983. Perilaku Organisasi Konsep Dasar dan Aplikasinya. Jakarta. CV. Rajawali.

Mas'ud. Fuad. 2004. Survai Diagnosis Organisasional Konsep Dan Aplikasi. Badan Penerbit Universitas Dipenogoro. Semarang.

Nawawi, Hadari. 2003. Manajemen Sumber Daya Manusia . UGM Pres.Yogyakarta.

Nurjanah. 2008. "Pengaruh Gaya Kepemimpinan dan Budaya Organisasi Terhadap Komitmen Organisasi Dalam Meningkarkan Kinerja Karyawan pada Biro Lingkup Departemen Pertanian",Tesis Pascasarjana (tidak diterbitkan).Semarang. Universitas Diponegoro

Noe Raymond A, John R Hollenbeck Barry Gerhart dan Patrick M Wright. 2011. Manajemen Sumber Daya Manusia. Penerbit salemba empat. Jakarta.

Payaman J. Simanjuntak. 2005. Manajemen dan Evaluasi Kinerja. Lembaga
Penerbit Fakultas Ekonomi UI. Jakarta.

Porwani, Sri 2009. "Dalam jurnal penelitiannya yang berjudul Pengaruh Budaya Organisasi, Gaya kepemimpinan Transformasional terhadap Kinerja Karyawan. PT Tabang Batubara Bukit Asam (Persero) Tanjung Enim".

Prawirosentono, Suyadi. 1999. Kebijakan Kinerja Karyawan. BPFE .Yogyakarta.

Pramudyo, Chrisogonus. D. 2007. Cara Pinter Jadi Trainer. Percetakan Galang Press. Jakarta

Rivai, V dan Ahmad, F. Performance Appraisal (Sistem yang Tepat untuk menilai kinerja karyawan dan meningkatkan daya saing perusahaan. Raja Grafindo Persada. Jakarta. 2005.

Rahman Safdar. 2010. Impact of Job Analysis On Job Performance : Analysis of Hypothesized Model.

Rivai, Veithzal. 2004. Manajemen Sumber Daya Manusia Untuk Perusahaan. Raja grafindo Persada. Jakarta.

Robbins, Stephen P. 2008. Perilaku Organisasi, Buku I.Alih Bahasa: Diana Angelica. Salemba Empat. Jakarta.

Seno Andri. 2008. "Pengaruh gaya Kepemirnpinan, Budaya Organisasi, Motivasi, Program

Sutrisno, 2009, Manajemen Keuangan teori, Konsep dan Aplikasi, Edisi pertama, Cetakan ketujuh, Ekonisia

Simamora, Heny. 2004. Manajemen Sumber Daya Manusia. Edisi Ke-3. STIE YKPN. Yogyakarta.

Tika, M. Pabundu. 2008. Budaya Organisasi dan Peningkatan Kinerja Perusahaan. Bumi Aksara. Jakarta.

Tomoki Sekiguchi. 2008. "The Role of Job Embededness on Employee Performance: The Interactive Effects With Leader-Member Exchange and Organization Base Self Esteem". Personnel Psychology vol .61, 2008. Hal 761-792. 